\title{
Review Paper: A Systematic Review of the Effectiveness of Early Intervention and the Role of Parents in Language Development of Hearing Loss Children
}

\author{
Ehsan Shekari ${ }^{1}$, Mahbubeh Nakhshab ${ }^{2,3}$, Vahid Valinejad ${ }^{4 *}$, Amin Modarres Zadeh ${ }^{4}$, Amirhossein Hosseinpour ${ }^{5}$ \\ 1. Department of Neuroscience, School of Advanced Technologies in Medicine, Iran University of Medical Sciences, Tehran, Iran. \\ 2. Department of Speech Therapy, University of Social Welfare and Rehabilitation Sciences, Tehran, Iran. \\ 3. Department of Speech Therapy, School of Rehabilitation Sciences, Isfahan University of Medical Sciences, Isfahan, Iran \\ 4. Department of Speech Therapy, School of Rehabilitation, Tehran University of Medical Sciences, Tehran, Iran. \\ 5. Department of Counseling, University of Social Welfare and Rehabilitation Sciences, Tehran, Iran.
}

Article info:

Received: 25 Nov. 2016

Accepted: 01 Feb. 2017

\section{Keywords:}

Early intervention, Early diagnosis, Hearing loss, Family-centered programs
Citation: Shekari E, Nakhshab M, Valinejad V, Modarres Zadeh A, Hosseinpour A. A Systematic Review of the Effectiveness of Early Intervention and the Role of Parents in Language Development of Hearing Loss Children. Iranian Rehabilitation Journal. 2017; 15(1):5-14. https://doi.org/10.18869/nrip.irj.15.1.5

https://doi.org/10.18869/nrip.irj.15.1.5 


\section{Introduction}

H

earing loss is a disabling condition in children that reduces the resolution capability of speech inquiry and disturbs the correct understanding of speech and learning [1]. Each year, over 718,000 babies are born with bilateral permanent hearing loss or obtain it in the early months of infancy. On an average, 2000 children with permanent hearing loss are born every day or obtain it during the early months of infancy [2]. Failure to detect hearing loss in its initial stages can negatively affect speech, language, cognitive and psychosocial development, and consequently, damage vocational attainment, particularly during the growth period [3]. In addition, hearing loss leads to unpleasant experiences in families and expose them to stress. The birth of a child with hearing loss has a feelings for parent which looks like an experience of bereavement [4]. Therefore, among all sensory disabilities in early childhood, permanent hearing damage from birth or during infancy is an important issue [3]

In the auditory system, the period when the brain's plasticity is high and ready to develop through stimulation is considered to be critical. Therefore, it is assumed that due to the rapid advancement of the brain in the plasticity period in early life, a child can acquire age-appropriate speech and language abilities when stimulations are presented in this sensitive period Since neuroplasticity decreases with age, it is logical to believe that the capacity of children to acquire these abilities is limited with time [5].

Lack of auditory sense reduces sensory stimulations of the brain. In addition to preventing auditory learning, sensory deprivation also prevents the nerve growth and reduces brain plasticity. Moreover, this pauses the growth of the auditory centers and destroys the auditory ways [6]. The development of language in deaf and hard-of-hearing children is relatively slow, and linguistic deficits are commonly seen in hearing-impaired children. Deficits in all areas of language, including syntax, morphology, phonological, semantic, and pragmatic aspects affect the reading and academic skills of hearing-impaired children [7]. However, the following three factors can facilitate oral language acquisition in children with all levels of hearing loss: 1) Early detection of hearing issues through universal auditory screening program for newborns; 2) Early intervention; and 3) Advances in auditory technology.

In Singapore, auditory screening is performed in approximately $99.95 \%$ of children from birth to 6 weeks. Hearing aids can also be used from 1.5 months of age [8]. In 2013,
Amiri and colleagues conducted a study on 25073 children in Ahvaz and reported that $92 \%$ of newborn hearing problems is diagnosed before 3 months of age [9].

Among the various hearing aids, cochlear implantation is widely used in hearing-impaired children. Cochlear implants help people with deep sensorineural hearing loss to attain a high level of speech perception. However, many individual variables affect the use of cochlear implantation and the perception of spoken sounds. In pre-linguistic children who have been diagnosed with profound sensorineural hearing loss, cochlear implants can provide a great opportunity to learn the expressive language [10]. With early identification of hearing impaired children, early interventions have also led to more natural approaches. In these approaches, parents and caregivers are used as the providers of medical services [11]

Today, family training is essential for every family having children with special needs. From this point of view, designing and formulating family-oriented educational programs is of importance. Educational programs for family increase awareness and skill-training and help parents improve their interactions with their child [12]. After the diagnosis of hearing impairment (deaf/hard-of-hearing) in children, a suitable, personalized, objective and welldefined treatment plan is needed. For an infant or young child is deaf or hard of hearing $\mathrm{D} / \mathrm{HH}$ to reach their full potential, intervention personal carefully planned should be performed, by means of care providers with the knowledge and skills of optimal and services based on research, best practices, and proven models. EI service provider is complicated and requires an individual to respond to the identified needs of children and families [13].

Evidence show that early interventions provide necessary conditions for the young children (birth to 36 months of age) to eliminate barriers to growth and minimize or eliminate other problems of hearing-impaired children. Early intervention facilitates and accelerates the overall development of the children through providing education that other children normally acquire. It teaches families how to communicate with their children with special needs and provide education services for them [14]. Vygotsky (1986), who is one of the most influential thinkers in developmental psychology, believes that the development of an individual is a social process during which children's interaction with others changes them from a creature who responds to stimulation to a thinking human being who is a part of society. In his view, these changes are rooted in children's culture and obtained through the use of unique oral language [15]. 
Since the interaction between the child and the family is important for the development of linguistic and mental skills of children, a part of recent research in psychology have focused on this aspect.

One of the most interesting studies in this context is the study by Fantuzzo and McWayne (2002). Their study was conducted in the North-East urban educational areas of the US, which comprised mainly low-income African Americans families. They used various quantitative tools for evaluating the interaction of families with children, the child's learning style, lexical development, and behavior of children in the class. They found that the interaction of parents with children has a strong positive effect on the child's learning and behavior in the classroom. They concluded that home interactive activities such as reading to children, asking children regarding their activities in school, and training courses with them, have the strongest relationship with academic achievement of children in the future [16].

Rasinski and Stevenson (2005) evaluated the effect of parent training in increasing the verbal abilities of firstgrade children with hearing impairment. In this study, the experimental group consisted of 15 parents who received direct education through books, pamphlets, and consolidated guides. The control group consisted of 15 families that received only general advice in school. After 11 weeks, the reading ability of children increased significantly in the experimental group than the control group. It was also found that any educational program that is designed for parents should have these 8 characteristics: 1) The program should be significant for parents; 2 ) The program should be appropriate for suffering children in terms of their development; 3) Educational program should be based on the school curriculum or skills that parents like; 4) Learning educational materials should be easy for parents; 5) The program should not take too much of the family time; 6) The program should be designed for each family member separately and proprietary; 7) Counseling should always be included in the program; 8) Situations to practice the learned skills should be created.

The linguistic interaction of parents with their hearingimpaired children takes a more complex shape due to problems in communication and mental states of the family. Desley and Perlmtor [17] found that children of parents who were qualified in comprehensive communication, i.e., using speech, writing with fingers, and using hand signs, scored more in psychometric tests of self-confidence than children whose parents had only verbal communication. Even communications between the second and third members of the family with hearing-impaired children have an effect on these children's ways of communication [17].
In a descriptive study of 10 families with hearing loss, Norton (2000) investigated the impacts of interaction between grandparents and child. He found that the understanding of the child, his/her acceptance, and support from the grandparents helped the children to be better involved in family life and activities. Speech therapists and teachers also played an important role in guiding parents to solve frequent problems with their hearingimpaired children [15].

Knowles (2008) investigated the parent's perceptions of the effect of early intervention on facilitating the transfer of children from home to school. He found that the parents viewed early intervention as a great responsibility that guided parents in providing transparent and comprehensive information and involved them in the treatment. In this study, parents reported that among the pressures they face during the children's growth period, communication problems with experts, including lack of provision of clear information, insufficient training, lack of adequate support to parents, and fear of the other factors, are problematic and stressful [18]. Given the role of early intervention in reducing the negative effects of hearing loss on the acquisition and development of speech and language, as well as the role of parents in carrying out these interventions, we tried to consider the previous studies in the field of early intervention and treatment based on parents of the hearing-impaired children.

\section{Methods}

For this systematic review, databases such as ISI Web of Knowledge, PubMed and Embase were searched for articles in the period from 1990 to 2014 . Key words like hard-of-hearing, deaf children, children with hearing loss, family's approach, parents' approach, parents' education, program(s), early detection, family education program(s), and early intervention were searched.

In order to increase the scope of the search, the references of the selected studies were further examined to find more related articles. The abstracts of articles were evaluated by the authors. The primary criterion was whether the paper accounted for the researcher's questions or not. The second stage of selection was based on the following criteria: Articles are written in English.

Article design type should be randomized controlled trial, case report, case series, pre/post, observational, and clinical consensus. Measurements of study include early intervention and the role of parents in treatment. 
Table 1. The main clinical results of the studies reviewed

\begin{tabular}{|c|c|c|c|c|c|c|}
\hline Results & $\begin{array}{l}\text { Age of Inter- } \\
\text { vention }\end{array}$ & $\begin{array}{l}\text { Type of Interven- } \\
\text { tion }\end{array}$ & $\begin{array}{c}\text { Type of Hearing } \\
\text { Loss }\end{array}$ & Sample & 竞 & 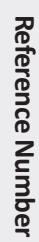 \\
\hline $\begin{array}{l}\text { Mothers who had higher } \\
\text { communication skills and their } \\
\text { children had higher language } \\
\text { and reading skills and lower } \\
\text { behavioral problems. Language } \\
\text { development was higher in } \\
\text { children whose mothers opted } \\
\text { for earlier interventions. }\end{array}$ & $\begin{array}{l}45 \text { to } 88 \\
\text { months of } \\
\text { follow-up } \\
\text { period }\end{array}$ & $\begin{array}{l}\text { Parent child inter- } \\
\text { action record }\end{array}$ & $\begin{array}{l}\text { Moderate to severe } \\
\text { hearing loss, senso- } \\
\text { rineural }\end{array}$ & $\begin{array}{l}28 \text { children with } \\
\text { moderate to } \\
\text { severe hearing } \\
\text { loss, sensorineu- } \\
\text { ral who were in } \\
\text { the pre-linguistic } \\
\text { stage }\end{array}$ & $\frac{\frac{Q}{D}}{\frac{D}{D}}$ & $\underline{\omega}$ \\
\hline $\begin{array}{c}\text { Improvements in verbal skills, } \\
\text { grammar, and vocabulary in a } \\
\text { way that was within the normal } \\
\text { range of age. }\end{array}$ & $\begin{array}{l}\text { Before } 12 \\
\text { months }\end{array}$ & $\begin{array}{l}\text { The effect of age } \\
\text { and cochlear } \\
\text { implantation on } \\
\text { language devel- } \\
\text { opment }\end{array}$ & $\begin{array}{c}\text { Congenital hearing } \\
\text { loss }\end{array}$ & $\begin{array}{l}3 \text { boys and one } \\
\text { girl with hearing } \\
\text { loss in pre- } \\
\text { lingual stage }\end{array}$ & 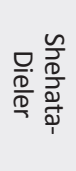 & $\underline{G}$ \\
\hline $\begin{array}{c}\text { Cochlear implant in early stages } \\
\text { improves the use of audio input } \\
\text { and the subsequent develop- } \\
\text { ment of the language. }\end{array}$ & $\begin{array}{l}12 \text { to } 38 \\
\text { months }\end{array}$ & $\begin{array}{l}\text { 30-minute parent } \\
\text { - child recording } \\
\text { sessions }\end{array}$ & $\begin{array}{l}\text { Congenital bilateral } \\
\text { and profound sen- } \\
\text { sorineural hearing } \\
\text { loss }\end{array}$ & $\begin{array}{l}\text { Children } 34 \\
\text { months to } 38 \\
\text { months }\end{array}$ & 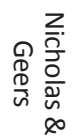 & 它 \\
\hline $\begin{array}{l}\text { The effectiveness of early } \\
\text { intervention depends on its ac- } \\
\text { ceptance by families. }\end{array}$ & & $\begin{array}{l}\text { Family inter- } \\
\text { ventions with } \\
\text { children }\end{array}$ & $\begin{array}{l}32 \text { moderate hear- } \\
\text { ing loss, } 17 \text { severe } \\
\text { hearing loss, and } 32 \\
\text { profound deafness }\end{array}$ & $\begin{array}{l}105 \text { parents of } \\
\text { children with } \\
\text { hearing loss }\end{array}$ & 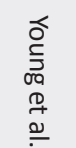 & 증 \\
\hline $\begin{array}{l}\text { Professionals should use family's } \\
\text { comments in determining their } \\
\text { intervention. }\end{array}$ & & $\begin{array}{l}\text { Family-centered } \\
\text { early intervention } \\
\text { program }\end{array}$ & & $\begin{array}{l}120 \text { mothers and } \\
60 \text { experts who } \\
\text { participated in } \\
\text { an early inter- } \\
\text { vention program }\end{array}$ & 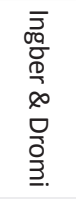 & $\stackrel{\sim}{\stackrel{N}{\ominus}}$ \\
\hline $\begin{array}{l}\text { Parent participation in the inter- } \\
\text { vention resulted in appropriate } \\
\text { language output in hearing- } \\
\text { impaired children. }\end{array}$ & $\begin{array}{l}\text { From } 2 \text { to } 52 \\
\text { months }\end{array}$ & $\begin{array}{l}\text { Verbal communi- } \\
\text { cation programs }\end{array}$ & $\begin{array}{c}\text { Congenital hearing } \\
\text { loss }\end{array}$ & $\begin{array}{l}32 \text { boys and } 25 \\
\text { girls aged } 1 \text { to } 6 \\
\text { years old }\end{array}$ & 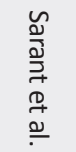 & $\stackrel{N}{N}$ \\
\hline $\begin{array}{l}\text { Socioeconomic status (SES) of } \\
\text { the family and the use of sign } \\
\text { language in family had an effect } \\
\text { on speech output of children } \\
\text { with hearing loss }\end{array}$ & $\begin{array}{l}9 \text { children had } \\
\text { no hearing aid, } \\
29 \text { children } \\
\text { used usual } \\
\text { hearing aids, } 2 \\
\text { children aged } \\
\text { less than } 2 \\
\text { years and } 19 \\
\text { children aged } \\
\text { between } 2 \\
\text { and } 5 \text { years re- } \\
\text { ceived cochlear } \\
\text { implants. }\end{array}$ & $\begin{array}{l}\text { Assess the } \\
\text { variables related } \\
\text { to children and } \\
\text { families }\end{array}$ & $\begin{array}{l}69 \% \text { of children } \\
\text { became deaf in pre- } \\
\text { lingual stage, and } 5 \\
\text { individuals became } \\
\text { deaf in post-lingual } \\
\text { stage. }\end{array}$ & $\begin{array}{l}42 \text { boys and } 32 \\
\text { girls in the group } \\
\text { of hearing- } \\
\text { impaired } \\
72 \text { boys and } 70 \\
\text { girls in the group } \\
\text { of children with } \\
\text { normal hearing }\end{array}$ & 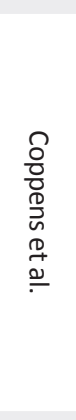 & $\underset{\widetilde{\omega}}{\widetilde{N}}$ \\
\hline $\begin{array}{l}\text { Higher language scores sig- } \\
\text { nificantly correlate with early } \\
\text { intervention and cooperation of } \\
\text { families. }\end{array}$ & $\begin{array}{l}\text { Age of enroll- } \\
\text { ment and } \\
\text { participation } \\
\text { in intervention } \\
\text { was from one } \\
\text { month to } 54 \\
\text { months. }\end{array}$ & $\begin{array}{l}\text { Early diagnosis } \\
\text { and early inter- } \\
\text { vention programs }\end{array}$ & $\begin{array}{l}\text { Mild to profound } \\
\text { hearing loss which } \\
\text { started in the pre- } \\
\text { lingual stage }\end{array}$ & $\begin{array}{l}58 \text { boys and } 54 \\
\text { girls }\end{array}$ & $\begin{array}{l}3 \\
\frac{1}{D} \\
\frac{D}{D}\end{array}$ & $\stackrel{N}{\Perp}$ \\
\hline
\end{tabular}




\begin{tabular}{|c|c|c|c|c|c|c|}
\hline Results & $\begin{array}{l}\text { Age of Inter- } \\
\text { vention }\end{array}$ & $\begin{array}{l}\text { Type of Interven- } \\
\text { tion }\end{array}$ & $\begin{array}{l}\text { Type of Hearing } \\
\text { Loss }\end{array}$ & Sample & 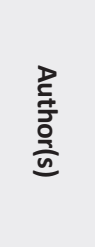 & 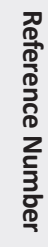 \\
\hline $\begin{array}{l}\text { Early enrollment in intervention } \\
\text { programs can improve language } \\
\text { development. }\end{array}$ & $\begin{array}{l}1.1 \text { months to } \\
9.50 \text { months }\end{array}$ & $\begin{array}{l}\text { Parent child inter- } \\
\text { action }\end{array}$ & $\begin{array}{l}\text { Bilateral hearing } \\
\text { loss; } 89 \% \text { was con- } \\
\text { genital . }\end{array}$ & $\begin{array}{l}79 \text { families who } \\
\text { had hearing-im- } \\
\text { paired children }\end{array}$ & 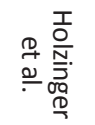 & $\underset{\widetilde{N}}{\widetilde{N}}$ \\
\hline $\begin{array}{c}\text { The emphasis on early interven- } \\
\text { tion and parent participation is } \\
\text { very helpful. }\end{array}$ & -------- & $\begin{array}{l}\text { Face to face } \\
\text { parent - child } \\
\text { interaction }\end{array}$ & $\begin{array}{l}15 \text { children with } \\
\text { severe to profound } \\
\text { hearing loss and } 5 \\
\text { patients had moder- } \\
\text { ate hearing loss. }\end{array}$ & $\begin{array}{l}40 \text { mothers with } \\
\text { normal hearing } \\
\text { with their } 20 \\
\text { children with } \\
\text { normal hearing } \\
\text { and } 20 \text { children } \\
\text { with moderate } \\
\text { to profound } \\
\text { hearing loss }\end{array}$ & 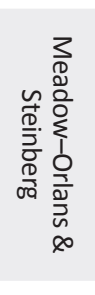 & $\stackrel{\bar{N}}{\widetilde{\sigma}}$ \\
\hline $\begin{array}{l}\text { Children who entered interven- } \\
\text { tion before } 6 \text { months of age had } \\
\text { higher language output com- } \\
\text { pared to the group that entered } \\
\text { after } 6 \text { months. }\end{array}$ & $\begin{array}{l}\text { From birth } \\
\text { to age } 34 / 4 \\
\text { months }\end{array}$ & $\begin{array}{l}\text { Home-based } \\
\text { services for family } \\
\text { education and } \\
\text { hearing-impaired } \\
\text { children }\end{array}$ & $\begin{array}{l}275 \text { sensorineural, } \\
22 \text { conductive, } 14 \\
\text { complex and } 17 \text { au- } \\
\text { ditory neuropathy }\end{array}$ & $\begin{array}{l}640 \text { infants and } \\
\text { children with } \\
\text { hearing loss }\end{array}$ & 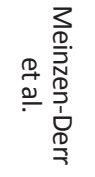 & $\sqrt[\mathbb{J}]{ }$ \\
\hline $\begin{array}{l}\text { Intervention before } 6 \text { months } \\
\text { has a remarkable effect on } \\
\text { language development. }\end{array}$ & $\begin{array}{l}15 \text { child before } \\
6 \text { months and } \\
25 \text { child after } \\
18 \text { months }\end{array}$ & $\begin{array}{l}\text { Colorado home } \\
\text { intervention } \\
\text { program CHIP }\end{array}$ & $\begin{array}{l}\text { Mild, } \\
\text { moderate,moderate } \\
\text { to severe, severe } \\
\text { and profound hear- } \\
\text { ing losss }\end{array}$ & $\begin{array}{l}40 \text { child and } \\
\text { their family }\end{array}$ & 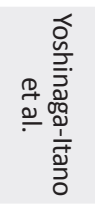 & $\underset{\infty}{\mathbb{\infty}}$ \\
\hline $\begin{array}{l}\text { Despite early identification } \\
\text { and intervention of hearing- } \\
\text { impaired children, language } \\
\text { abilities of these children were } \\
\text { lower than age-matched chil- } \\
\text { dren with normal hearing. }\end{array}$ & 1 to 5 months & $\begin{array}{l}\text { Early intervention } \\
\text { on the speech } \\
\text { communication } \\
\text { emphasized. }\end{array}$ & ------ & $\begin{array}{l}10 \text { deaf children } \\
\text { and } 10 \text { children } \\
\text { with normal } \\
\text { hearing }\end{array}$ & 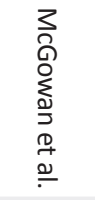 & $\widetilde{\widetilde{N}}$ \\
\hline $\begin{array}{l}\text { Parents can learn more appro- } \\
\text { priate interaction with the child. } \\
\text { Family must be less control- } \\
\text { ling and directing and more } \\
\text { responsive to their children's } \\
\text { communication efforts. }\end{array}$ & ------- & $\begin{array}{l}\text { Increase com- } \\
\text { munication skills } \\
\text { between parents } \\
\text { through home } \\
\text { visits }\end{array}$ & $\begin{array}{l}8 \text { children with } \\
\text { congenital hearing } \\
\text { loss and } 3 \text { children } \\
\text { with acquired hear- } \\
\text { ing loss }\end{array}$ & $\begin{array}{l}17 \text { parents of } 11 \\
\text { children who re- } \\
\text { ceived cochlear } \\
\text { implants }\end{array}$ & 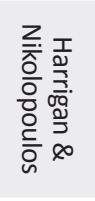 & జ్ \\
\hline $\begin{array}{l}\text { Communication behaviors of } \\
\text { parents, maternal stress, degree } \\
\text { of hearing loss and children stay } \\
\text { in the intensive care unit can } \\
\text { affect speech production. }\end{array}$ & 30 months & $\begin{array}{l}\text { Video recording } \\
\text { of parent - child } \\
\text { play }\end{array}$ & $\begin{array}{l}\text { Sustainable con- } \\
\text { genital hearing loss }\end{array}$ & $\begin{array}{c}40 \text { deaf children } \\
\text { and } 31 \text { children } \\
\text { with normal } \\
\text { hearing }\end{array}$ & $\begin{array}{l}\delta \\
\frac{\delta}{2} \\
\stackrel{0}{0} \\
\stackrel{0}{\rho}\end{array}$ & $\stackrel{\underset{\ominus}{\rightleftarrows}}{=}$ \\
\hline $\begin{array}{l}\text { Parents' stress affects the way } \\
\text { they communicate with their } \\
\text { children. }\end{array}$ & ----- & $\begin{array}{l}\text { Family-centered } \\
\text { early intervention } \\
\text { program }\end{array}$ & $\begin{array}{l}\text { Sustainable con- } \\
\text { genital hearing loss }\end{array}$ & $\begin{array}{l}30 \text { children with } \\
\text { hearing loss and } \\
91 \text { children with } \\
\text { normal hearing }\end{array}$ & 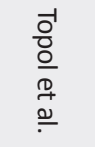 & $\stackrel{\underset{N}{\sim}}{\sim}$ \\
\hline $\begin{array}{l}\text { Age at intervention did not have } \\
\text { considerable effect on children's } \\
\text { language outcome. }\end{array}$ & $\begin{array}{l}45 \% \text { before } 6 \\
\text { months and } \\
55 \% \text { between } 6 \\
\text { and } 34 \text { months } \\
\text { received hear- } \\
\text { ing aids }\end{array}$ & $\begin{array}{l}\text { Auditory-verbal } \\
\text { program,auditory } \\
\text { with signs, and bi- } \\
\text { lingual programs }\end{array}$ & $\begin{array}{l}\text { Bilateral hearing } \\
\text { loss from mild to } \\
\text { severe }\end{array}$ & $\begin{array}{l}79 \text { boys and } 54 \\
\text { girl with hearing } \\
\text { loss }\end{array}$ & 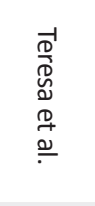 & $\stackrel{\widetilde{w}}{\widetilde{w}}$ \\
\hline $\begin{array}{l}\text { Parent's participation in inter- } \\
\text { vention for children with severe } \\
\text { to profound hearing loss was } \\
\text { effective even when they enter } \\
\text { in intervention at older ages. }\end{array}$ & 8 to 32 months & $\begin{array}{c}\text { Use parent } \\
\text { participation in } \\
\text { intervention scale }\end{array}$ & $\begin{array}{l}\text { Sustained hearing } \\
\text { loss from moderate } \\
\text { to severe }\end{array}$ & $\begin{array}{l}120 \text { children } \\
\text { in hearing loss } \\
\text { group and } 64 \\
\text { children in nor- } \\
\text { mal group }\end{array}$ & 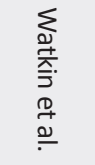 & $\underset{\varpi}{\varpi}$ \\
\hline
\end{tabular}




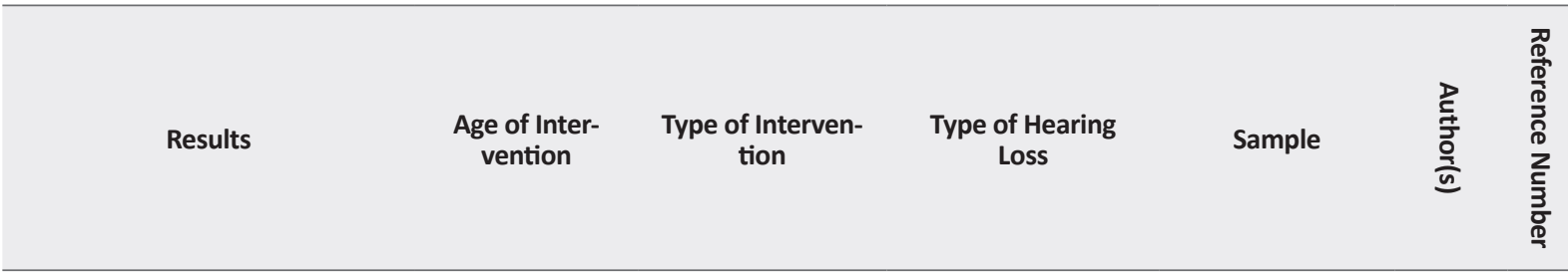

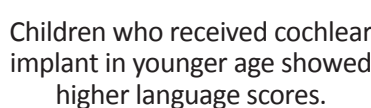

higher language scores.

\section{5 years to 6 years and 11 months}

\section{Family center early intervention program}

Most children affected by hearing loss in prelingual phase and a few in primary language development

\section{3 children with hearing loss

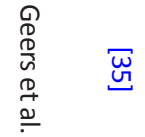

Early identification of hearing loss and early intervention makes remarkable language achievement.

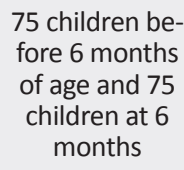

75 children before 6 months of age and 75 children at 6 months

Children with mild Person-centered moderate, severe, programs profound hearing loss
75 boys and 75 girls

Ilranian Rehabilitation Journal

This article must have examined different types of hearing loss among infants and children aged below 8 years. The article selection method used in this paper is shown in Figure 1.

\section{Results}

Based on the key words listed, 100 articles were initially found. But finally, only 20 studies were chosen for final review that suited the needs of this research. Table 1 summarizes the methodology, the details of the subjects, and the results of the chosen studies.

\section{Discussion}

The age of the child in the first intervention program of communication is a crucial factor in determining the rate of language acquisition. However, children with profound hearing loss achieved good speech-language skills if they received cochlear implants at a very young age along with verbal communication applications [22]. This shows that using hearing aids at a young age is an important factor in the development of speech and language skills in hearing-impaired children.

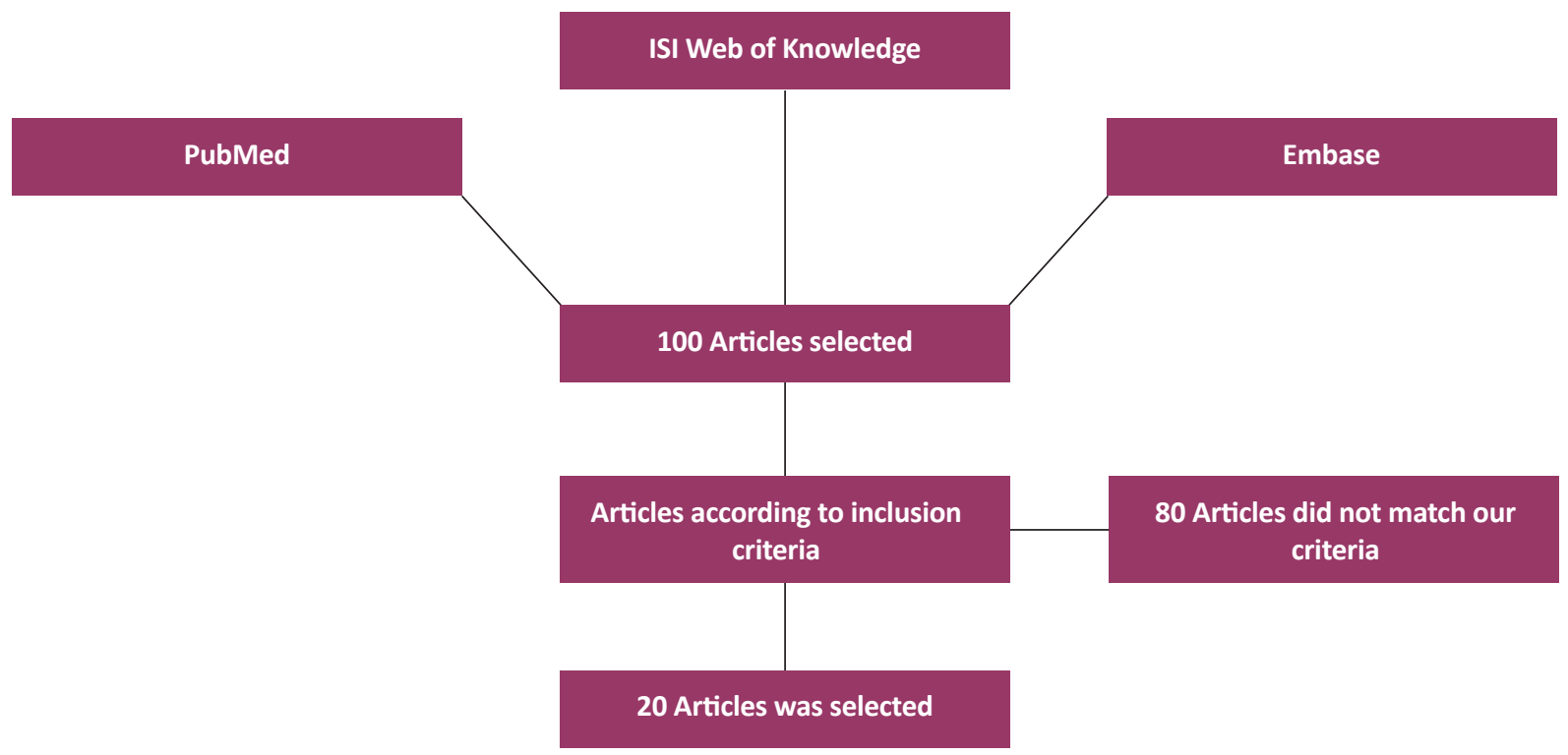

Figure 1. Article selection chart

Iranian Rehabilitation Journal 
Several studies have compared the age of detection and intervention and have shown that children with hearing loss who were diagnosed at 2 to 6 months of age have language development at par with children with the same chronological age. Children who were diagnosed after 6 months showed significant language delay compared to the normal population. The age at which the child undergoes intervention is also an important factor in predicting expressive language, understanding, discernment, listening, and speech production scores. The lack of significant differences in language scores in children who had been diagnosed at an age of 7 to 12,13 to 18,19 to 24 , and 25 to 30 months showed that the identification of hearing loss between 7 to 30 months of age had no significant effects on Language Quotient [32, 37].

According to reported studies, diagnosing hearing loss in children before the age of 6 months can improve the process of speech and language development skills, making their development similar to children with normal development. Also, there may be other different variables that may affect vocabulary development, speech and language skills of children with hearing loss. Such variables include parent participation in the intervention program, using sign language at home, intelligence, and no use of hearing aids.

Family participation, degree of hearing loss, and cognitive abilities significantly predict language outcome [22]. As the maternal communication skills provides an important predictor for language growth, early reading skills and social-emotional growth. Children with mothers who showed better communication skills with them had more speaking and reading scores and less behavioral problems [36]. Ching et al. reported that the educational level of parents of children with hearing loss has significant effects on language output [33]. The greatest progress was seen in children whose families had the highest level of participation in the early intervention program. In addition, limited involvement of the family led to delayed language development in children aged 5 years [24]. Therefore, the involvement of parents in training programs can be very effective in improving the language scores of children with hearing loss.

Studies have shown that parental stress increases behavioral problems and issues in speech production in hearingimpaired children. Therefore, parent's stress should be recognized and controlled for optimum intervention program to be carried out [30-32]. Moreover, family-based training programs can be more effective and efficient in controlling parent's negative factors like anxiety and stress.
The communication system of parents with child having hearing loss was another variable that was examined in many studies. Researchers have shown that there is a negative relationship between the use of sign language at home and vocabulary knowledge in reading. Thus, children who use sign language received lower input in oral language and therefore, had low vocabulary knowledge in reading [20]. It seems that reducing the use of sign language and using verbal language by parents may improve the growth of child's language skills.

Redsea (1995) evaluated the effect of early intervention on speech, language and auditory functions of young hearing-impaired children. In this study, he stated that the children's function in speech production has a significant relationship with the level of child's hearing loss, but the language scores was not significantly related to the level of hearing loss. The onset age of early intervention was also related with language scores such that a child's score in language assessment was higher when the intervention starts earlier [21].

In general, studies have shown that vocabulary development in hearing-impaired children is stable over time. In addition to the age of children at intervention and the role of parents, other factors such as educational status, use of sign language in the home, intelligence, use of hearing aids, and hearing impairment starts, may also cause differences between the hearing-impaired children and normal children $[23,33]$. Therefore, it is essential to consider the age of receiving hearing aids and parental involvement in intervention as the most important factors in children's education and designing treatment programs.

\section{Conclusion}

The first and the most important conclusion that can be deduced from this research is that hearing loss should be detected at the age of 6 months or less and that appropriate early intervention program can lead to the normal development of language skills in these children. But these interventions have the best results only if early diagnosis and the family participation are considered together. Early diagnosis can only be done through regular monitoring of hearing since birth in all the maternity and pediatric hospitals. Factors of family include several areas such as follows: 1) Family questions about the etiology of hearing loss, the treatment process, possible outcomes of treatment, and the duration of treatment; 2) Attention to the interaction between father, mother, siblings and grandparents of children with hearing impairment, from the time of diagnosis of hearing impairment, and if necessary, correct it; and 3) Overcome parents' depression 
and frustration, especially in mothers, by showing successfully treated cases and improvement in child progress on opting for appropriate treatment.

The above studies considered in this paper answer three important questions: 1) When hearing begins? 2) Whether the outcome of an early intervention outcome is the same for all hearing loss severities? 3) Can the results of these interventions be generalized to that of other language disorders?

Intervention should begin at an age of less than 6 months, especially during fetal life. The answer to the second question plays an important role in speech and language development theories and the importance of hearing in them. And if the interventions in this population of children can be implemented in all children at risk, one comprehensive communication early intervention protocol can be achieved. These three cases themselves require very precise study and the need for them is felt especially inside our country as well.

\section{Acknowledgments}

This research did not receive any specific grant from funding agencies in the public, commercial, or not-forprofit sectors. The author wishes to thank Mr. Mohammad Amin Modareszadeh and Mr. Mohsen Shekari for their help in writing this paper.

\section{Conflict of Interest}

The authors declared no conflicts of interest.

\section{References}

[1] Northern JL, Downs MP. Hearing in children. Philadelphia: Williams \& Wilkins; 2002.

[2] Stewart TM. The relationship of attitudes and intentions to behave to the acquisition of fluent speech behaviour by stammerers. International Journal of Language \& Communication Disorders. 1982; 17(2):3-13. doi: 10.3109/13682828209012215

[3] Calderon R. Parental involvement in deaf children's education programs as a predictor of child's language, early reading, and social-emotional development. Journal of Deaf Studies and Deaf Education. 2000; 5(2):140-55. doi: 10.1093/ deafed/5.2.140

[4] Foroughan M, Movallali G, Salimi M, Asad-Malayeri S. [The effectiveness of a group counseling program on the mental health of parents of hearing impaired children (Persian)]. Audiology. 2006; 15(2):53-60.

[5] May-Mederake B, Shehata-Dieler W. A case study assessing the auditory and speech development of four children im- planted with cochlear implants by the chronological age of 12 months. Case Reports in Otolaryngology. 2013; 2013:1-10. doi: $10.1155 / 2013 / 359218$

[6] Uus K, Bamford J. Effectiveness of population-based newborn hearing screening in England: Ages of interventions and profile of cases. Pediatrics. 2006; 117(5):887-93. doi: 10.1542/ peds.2005-1064

[7] Fung PC, Chow BWY, McBride-Chang C. The impact of a dialogic reading program on deaf and hard-of-hearing kindergarten and early primary school-aged students in Hong Kong. Journal of Deaf Studies and Deaf Education. 2005; 10(1):82-95. doi: 10.1093/deafed/eni005

[8] Lim LH. A multidisciplinary approach to paediatric hearing loss: programme at the centre for hearing intervention and language development, National University Hospital, Singapore. Annals of the Academy of Medicine Singapore. 2008; 37(12):57-3. PMID: 19904451

[9] Amiri M, Ghoochani Z, Haghighizadeh MH, Nilehchi Z. [Neonatal hearing screening program in Ahvaz, Southern Iran (Persian)]. Audiology. 2014; 22(4):69-77.

[10] Frisch SA, Pisoni DB. Modeling spoken word recognition performance by pediatric cochlear implant users using feature identification. Ear and Hearing. 2000; 21(6):578-589. doi 10.1097/00003446-200012000-00005

[11] Muma J, Perigoe C. Professional preparation: Developing language in children with hearing loss. The Volta Review. 2010; 110(2):179-190

[12] Movallali G, Dousti M, Abedi-Shapourabadi S. The effectiveness of positive parenting program (triple $\mathrm{P}$ ) on mental health of parents of hearing impaired children. Journal of Applied Environmental and Biological Sciences. 2015; 5(5S):28690.

[13] Yoshinaga-Itano C. Principles and guidelines for early intervention after confirmation that a child is deaf or hard of hearing. Journal of Deaf Studies and Deaf Education. 2013; 19(2):143-157. doi: 10.1093/deafed/ent043

[14] Ball J. Early intervention \& autism: Real-life questions, reallife answers. Arlington: Future Horizons; 2008.

[15] Brown-Levey S. The role parents play in deaf children's language and communication skills development. New York: State University of New York; 2004.

[16] Fantuzzo J, McWayne C. The relationship between peer-play interactions in the family context and dimensions of school readiness for low-income preschool children. Journal of Educational Psychology. 2002; 94(1):79-87. doi:10.1037//0022-0663.94.1.79

[17] Rasinski T, Stevenson B. The effects of fast start reading: a fluency-basedhome involvement reading program, on the reading achievement of beginning readers. Reading Psychology. 2005; 26(2):109-25. doi: 10.1080/02702710590930483

[18] Evans H. Technological early intervention tools for families of children with hearing loss: Parental learning preferences [PhD thesis]. Minneapolis:Walden University; 2008.

[19] Nicholas JG, Geers AE. Effects of early auditory experience on the spoken language of deaf children at 3 years of age. Ear and Hearing. 2006; 27(3):286-298. doi: 10.1097/01. aud.0000215973.76912.c6 
[20] Young A, Gascon-Ramos M, Campbell M, Bamford J. The design and validation of a parent-report questionnaire for assessing the characteristics and quality of early intervention over time. Journal of Deaf Studies and Deaf Education. 2009; 14(4):422-35. doi: 10.1093/deafed/enp016

[21] Ingber S, Dromi E. Actual versus desired family-centered practice in early intervention for children with hearing loss. Journal of Deaf Studies and Deaf Education. 2010; 15(1):59-71. doi: 10.1093/deafed/enp025

[22] Sarant JZ, Holt CM, Dowell RC, Rickards FW, Blamey PJ. Spoken language development in oral preschool children with permanent childhood deafness. Journal of Deaf Studies and Deaf Education. 2008; 14(2):205-217 doi: 10.1093/deafed/ enn034.

[23] Coppens KM, Tellings A, van der Veld W, Schreuder R, Verhoeven L. Vocabulary development in children with hearing loss: The role of child, family, and educational variables. Research in Developmental Disabilities. 2012; 33(1):119-28. doi: 10.1016/j.ridd.2011.08.030

[24] Moeller MP. Early intervention and language development in children who are deaf and hard of hearing. Pediatrics. 2000; 106(3):1-9. doi: 10.1542/peds.106.3.e43

[25] Holzinger D, Fellinger J, Beitel C. Early onset of family centred intervention predicts language outcomes in children with hearing loss. International Journal of Pediatric Otorhinolaryngology. 2011; 75(2):256-60. doi: 10.1016/j.ijporl.2010.11.011

[26] Meadow-Orlans KP, Steinberg AG. Effects of infant hearing loss and maternal support on mother-infant interactions at 18 months. Journal of Applied Developmental Psychology. 1993; 14(3):407-26. doi: 10.1016/0193-3973(93)90017-p

[27] Meinzen-Derr J, Wiley S, Choo DI. Impact of early intervention on expressive and receptive language development among young children with permanent hearing loss. American Annals of the Deaf. 2011; 155(5):580-91. doi: 10.1353/ aad.2011.0010

[28] Yoshinaga-Itano C, Mah-Rya LA. Identification of hearing loss after age 18 months is not early enough. American Annals of the Deaf. 1998; 143(5):380-7. doi: 10.1353/aad.2012.0151

[29] McGowan RS, Nittrouer S, Chenausky K. Speech production in 12-month-old children with and without hearing loss. Journal of Speech, Language, and Hearing Research. 2008; 51(4):879-88. doi: 10.1044/1092-4388(2008/064)

[30] Harrigan S, Nikolopoulos TP. Parent interaction course in order to enhance communication skills between parents and children following pediatric cochlear implantation. International Journal of Pediatric Otorhinolaryngology. 2002; 66(2):161-6. doi: 10.1016/s0165-5876(02)00243-4

[31] Vohr B, St Pierre L, Topol D, Jodoin-Krauzyk J, Bloome J, Tucker R. Association of maternal communicative behavior with child vocabulary at $18-24$ months for children with congenital hearing loss. Early Human Development. 2010; 86(4):255-60. doi: 10.1016/j.earlhumdev.2010.04.002

[32] Topol D, Girard N, Pierre LS, Tucker R, Vohr B. The effects of maternal stress and child language ability on behavioral outcomes of children with congenital hearing loss at 18-24months. Early Human Development. 2011; 87(12):80711. doi: 10.1016/j.earlhumdev.2011.06.006
[33] Ching TY, Crowe K, Martin V, Day J, Mahler N, Youn S, et al. Language development and everyday functioning of children with hearing loss assessed at 3 years of age. International Journal of Speech-Language Pathology. 2010; 12(2):124-31. doi: 10.3109/17549500903577022

[34] Watkin P, McCann D, Law C, Mullee M, Petrou S, Stevenson J, et al. Language ability in children with permanent hearing impairment: The influence of early management and family participation. Pediatrics. 2007; 120(3):e694-e701. doi: 10.1542/peds.2006-2116

[35] Geers AE, Moog JS, Biedenstein J, Brenner C, Hayes H. Spoken language scores of children using cochlear implants compared to hearing age-mates at school entry. Journal of Deaf Studies and Deaf Education. 2009; 14(3):371-85. doi: 10.1093/deafed/enn046

[36] Swanepoel D, Störbeck C, Friedland P. Early hearing detection and intervention in South Africa. International Journal of Pediatric Otorhinolaryngology. 2009; 73(6):783-6. doi: 10.1016/j.ijporl.2009.01.007

[37] Yoshinaga-Itano C. From screening to early identification and intervention: Discovering predictors to successful outcomes for children with significant hearing loss. Journal of Deaf Studies and Deaf Education. 2003; 8(1):11-30. doi: 10.1093/deafed/8.1.11 
